\title{
Observations of PAN and its confinement in the Asian summer monsoon anticyclone in high spatial resolution
}

\author{
Jörn Ungermann, Mandfred Ern, Martin Kaufmann, Rolf Müller, Reinhold Spang, Felix Ploeger, Bärbel Vogel, and \\ Martin Riese
}

Institut für Energie- und Klimaforschung - Stratosphäre (IEK-7), Forschungszentrum Jülich GmbH, Jülich, Germany

Correspondence to: Jörn Ungermann (j.ungermann@fz-juelich.de)

Received: 14 January 2016 - Published in Atmos. Chem. Phys. Discuss.: 1 February 2016

Revised: 30 May 2016 - Accepted: 15 June 2016 - Published: 12 July 2016

\begin{abstract}
This paper presents an analysis of trace gases in the Asian summer monsoon (ASM) region on the basis of observations by the CRISTA infrared limb sounder taken in low-earth orbit in August 1997. The spatially highly resolved measurements of peroxyacetyl nitrate (PAN) and $\mathrm{O}_{3}$ allow a detailed analysis of an eddy-shedding event of the ASM anticyclone. We identify enhanced PAN volume mixing ratios (VMRs) within the main anticyclone and within the eddy, which are suitable as a tracer for polluted air originating in India and China. Plotting the retrieved PAN VMRs against potential vorticity (PV) and potential temperature reveals that the PV value at which the PAN VMRs exhibit the strongest decrease with respect to PV increases with potential temperature. These PV values might be used to identify the extent of the ASM. Using temperature values also derived from CRISTA measurements, we also computed the location of the thermal tropopause according to the WMO criterion and find that it confines the PAN anomaly vertically within the main ASM anticyclone. In contrast, the shed eddy exhibits enhanced PAN VMRs for 1 to $2 \mathrm{~km}$ above the thermal tropopause. Using the relationship between PAN as a tropospheric tracer and $\mathrm{O}_{3}$ as a stratospheric tracer to identify mixed air parcels, we further found the anticyclone to contain few such air parcels, whereas the region between the anticyclone and the eddy as well as the eddy itself contains many mixed air parcels. In combination, this implies that while the anticyclone confines polluted air masses well, eddy shedding provides a very rapid horizontal transport pathway of Asian pollution into the extratropical lowermost stratosphere with a timescale of only a few days.
\end{abstract}

\section{Introduction}

The Asian summer monsoon (ASM) anticyclone is the dominant circulation pattern in the summertime Northern Hemisphere in the upper troposphere/lower stratosphere (UTLS). It has a major impact on stratosphere-troposphere exchange (STE) and thus on the trace gas composition of the northern lowermost stratosphere and tropical upper troposphere. It is caused by persistent thermal heating during summer with a thermal low at lower altitudes and a strong anticyclone in the upper troposphere (e.g. Krishnamurti and Bhalme, 1976). The ASM can be found in the larger vicinity of the Tibetan Plateau and is enclosed by the subtropical westerly jet on its northern side and the tropical easterly jet on its southern side (e.g. Randel and Park, 2006). These jets act as a strong transport barrier and prevent the air inside the anticyclone from mixing along isentropic levels into the extratropical lower stratosphere or the equatorial tropics (e.g. Park et al., 2008). Previous studies using satellite data have thus found an enhancement of carbon monoxide (e.g. Li et al., 2005; Park et al., 2007) and other trace gases in the ASM, indicating that polluted air is trapped within the anticyclone below the thermal tropopause (Park et al., 2008). The ASM is largely responsible for the moistening of the lowermost stratosphere in summer (e.g. Gettelman et al., 2004; Ploeger et al., 2013). It is, however, not fully clear how much of the STE occurs isentropically, by eddy shedding, or vertically across the tropopause (e.g. Hsu and Plumb, 2000; Randel et al., 2010; Vogel et al., 2015; Garny and Randel, 2016).

The CRyogenic Infrared Spectrometers and Telescopes for the Atmosphere (CRISTA; e.g. Offermann et al., 1999) experiment was flown on two Space Shuttle missions (STS66 and STS85) in November 1994 and August 1997 respec- 
tively. During free-flying periods of about 10 days, global observations of temperature and numerous trace gases were made with unprecedented and so far unmatched spatial resolution (Riese et al., 1997, 1999). It was designed to examine dynamical processes primarily in the stratosphere and mesosphere, but it also measured the UTLS region.

By using three viewing directions simultaneously, a horizontal across-track sampling of $600 \mathrm{~km}$ was achieved. The along-track sampling was 200 to $400 \mathrm{~km}$, depending on the measurement mode. The vertical sampling was $1.5 \mathrm{~km}$ in the first mission and $2 \mathrm{~km}$ in the second mission (Grossmann et al., 2002). The spectral resolution was sufficient to determine 25 trace gas species (Offermann et al., 1999). While more recent satellites offer marginally better vertical resolution in the UTLS (especially solar occultation instruments such as ACE-FTS; Bernath et al., 2005) or a higher spectral resolution (such as MIPAS; Fischer et al., 2008), no other instrument since has offered such a spatial measurement density.

Here, we will examine the confinement of polluted air within the ASM by means of trace gases retrieved from CRISTA-2 measurements (that is measurements taken during the second CRISTA mission) taken in August 1997. We focus on peroxyacetyl nitrate (PAN) measurements, which offer the highest contrast between tropospheric air within the anticyclone and clean air outside compared to other tracers available from CRISTA measurements.

PAN is a tracer of tropospheric pollution. It is a secondary pollutant that forms in the troposphere from precursors whose main sources are biomass burning and anthropogenic pollution (e.g. Stephens, 1969; Penketi et al., 1975; Singh et al., 1986; Wunderli and Gehrig, 1991; Singh et al., 2007). Its lifetime is highly temperature dependent and it may be only seconds in the boundary layer but, close to the cold-point tropopause, PAN can accumulate for weeks or months (Roberts, 1990). The combination of the relatively long lifetime of PAN at tropopause altitudes together with the confinement of air in the ASM anticyclone is expected to lead to an accumulation of PAN in the ASM circulation. Further sources of PAN are thunderstorms in convective systems that produce $\mathrm{NO}_{\mathrm{x}}$ by lightning. The typical sinks are thermal decomposition at lower altitudes and photolysis in the stratosphere. Due to the low temperatures prevalent in the ASM anticyclone, PAN is well suited to identify polluted air masses that have been uplifted in the current season. For example, PAN was also used in model studies to determine the influence of regional emissions on the air within the ASM (e.g. Fadnavis et al., 2014). The first global dataset of PAN retrieved from satellites was provided by Glatthor et al. (2007) and Wiegele et al. (2012), covering the time frame from 2002 until the end of the MIPAS experiment in 2012. The newly derived data presented here show the global state 5 years earlier, although only for 1 week, and thus extends our knowledge of the historical evolution of PAN in the UTLS.

\section{Measurements and model data}

The measurements presented in this paper were made aboard the Space Shuttle experiment CRISTA. The limb sounder CRISTA was integrated into the astronomical Shuttle Pallet System (ASTRO-SPAS; Wattenbach and Moritz, 1997) and launched into orbit by the NASA space shuttle for two missions: once in November 1994 (CRISTA-1) and once in August 1997 (CRISTA-2). The instrument employs three Herschel telescopes (pointing towards $-18,0$, and $18^{\circ}$ in reference to the viewing direction, which varied, depending on the latitude, between 108 and $252^{\circ}$ with respect to flight direction Grossmann et al., 2002), four Ebert-Fastie spectrometers (Fastie, 1991), and 24 mid-infrared detectors ranging from 155 to $2390 \mathrm{~cm}^{-1}$ and covered an altitude range from $\approx 9$ to $150 \mathrm{~km}$ altitude in the limb. Here, we focus on the detector channels covering the spectral range from 777 to $862 \mathrm{~cm}^{-1}$ (with a spectral resolution of $\lambda / \Delta \lambda \approx 500$ ) more relevant to this work and the altitude range between 9 and $45 \mathrm{~km}$. The field of view has a size of $3 \mathrm{arcmin} \times 30 \mathrm{arcmin}$, which corresponds to about $1.7 \mathrm{~km} \times 17 \mathrm{~km}$ at $18 \mathrm{~km}$ tangent height, whereby spectra were usually measured in $2 \mathrm{~km}$ altitude steps. The typical along-track sampling for the three measurement tracks and the discussed measurements is $\approx 250 \mathrm{~km}$, while the typical across-track sampling is $\approx 600 \mathrm{~km}$. As the detectors and the optics were cooled by cryogenic helium, a high measurement speed could be achieved in combination with a good signal-to-noise ratio recording one spectrum took only $1.2 \mathrm{~s}$, allowing the measurement of full profiles in less than 1 min with four spectrometers operating in parallel. The vertical sampling is one spectrum every $2 \mathrm{~km}$, which, taking field of view and processing into account, translates to a vertical resolution of the retrieved products of $\approx 2 \mathrm{~km}$ for temperature and $\mathrm{O}_{3}$ and $\approx 3 \mathrm{~km}$ for PAN in the UTLS. As the retrieval grid is aligned with the tangent altitudes of the measured spectra, there is no loss of resolution due to interpolation. No limb sounder since has achieved a comparable spatial measurement density at this vertical resolution.

Previous work on CRISTA concentrated mainly on the exploration of the middle atmosphere, with only few studies looking on the UTLS region (e.g. Spang et al., 2015). Here, we examine the ASM, which was observed for 8 consecutive days from 8 to 16 August 1997 during the CRISTA-2 mission.

The calibrated spectra were available from previous studies (Spang et al., 2015). The level 2 processing was redone based on previous work for the atmospheric successor instrument CRISTA-NF (e.g. Ungermann et al., 2012). The JUelich Rapid Spectral SImulation Code V2 (JURASSIC2; e.g. Hoffmann et al., 2008; Ungermann, 2013) forward model is used to simulate radiances for given atmospheric states, while the Juelich Tomographic Inversion Library (JUTIL; e.g. Ungermann et al., 2015) performs the actual inversion to derive atmospheric quantities from mea- 

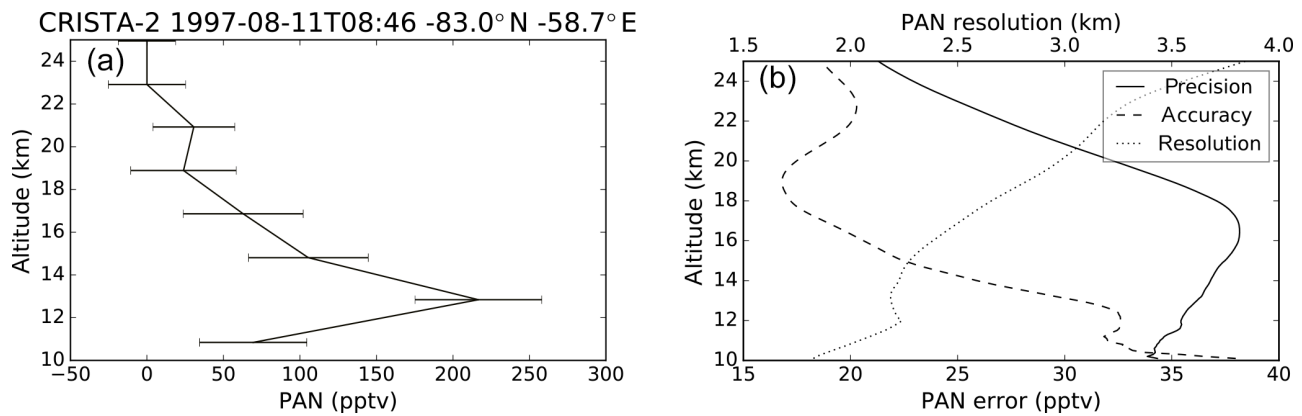

Figure 1. An exemplary retrieved PAN profile and diagnostic information. Panel (a) shows PAN on the retrieval grid with the precision given as error bars. Panel (b) shows average diagnostic values for precision (measurement noise induced error), accuracy (other, likely systematic, error sources, the leading one being elevation angle uncertainty, here), and resolution (full width at half maximum of averaging kernel matrix row).
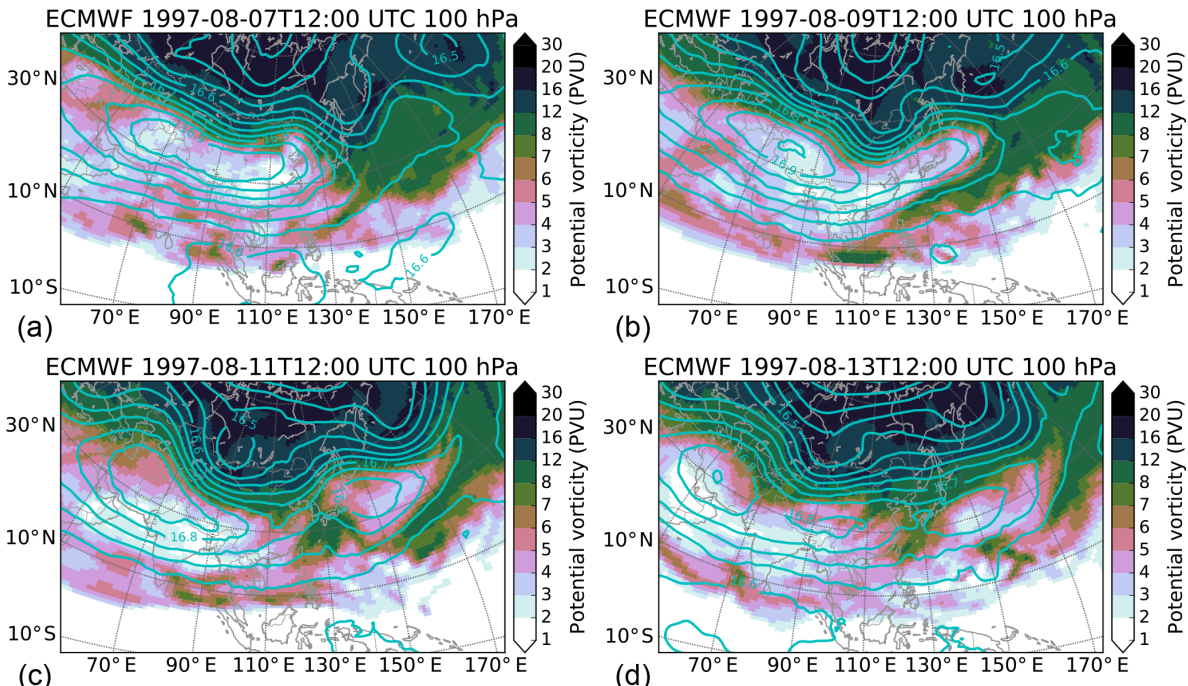

Figure 2. Potential vorticity (in PVU) derived from ECMWF ERA-Interim model data on $100 \mathrm{hPa}$. The contour lines show geopotential altitude (in kilometres).

sured infrared radiances. The set-up was slightly modified from the one used for the CRISTA-NF retrievals to accommodate the fact that the CRISTA spectra are interpolated onto a fixed 0.35 wavenumber grid and that the spectral range of the detector was smaller. The resulting set-up allows temperature, water vapour, ozone, nitric acid, PAN, carbon tetrachloride, CFC-11, CFC-113, and HCFC-22 to be derived, as well as the aerosol background level. Further quantities may be derived by incorporating spectral data acquired by other CRISTA detectors. The retrieval process is briefly described in Appendix A. An exemplary profile of PAN and diagnostic data averaged over retrieved profiles in the ASM region is shown in Fig. 1.

For analysis of the meteorological setting (pressure, temperature, wind speeds) and also as initial guess (temperature) and a priori (temperature and pressure) for the retrieval, ERA-Interim data supplied by the European Centre for Medium-range Weather Forecasts (ECMWF) were used
(Dee et al., 2011). For August 1997, these data are available in $6 \mathrm{~h}$ time steps in the T255/L60 resolution. Winds from this dataset were also used for calculation of air parcel trajectories with the Chemical Lagrangian Model of the Stratosphere (CLaMS; e.g. McKenna et al., 2002; Konopka et al., 2010).

\section{Analysis}

\subsection{Synoptic situation}

The majority of the CRISTA-2 measurements in the altitude region of the ASM falls in the period between 8 and 13 August due to the employed measurement mode. Figure 2 shows the approximate extent of the ASM on the $100 \mathrm{hPa}$ surface with low potential vorticity (PV) as a marker for air from inside the anticyclone and contour lines of geopotential altitude showing the geostrophic wind and thus the jets forming the horizontal transport barrier. In the beginning of 

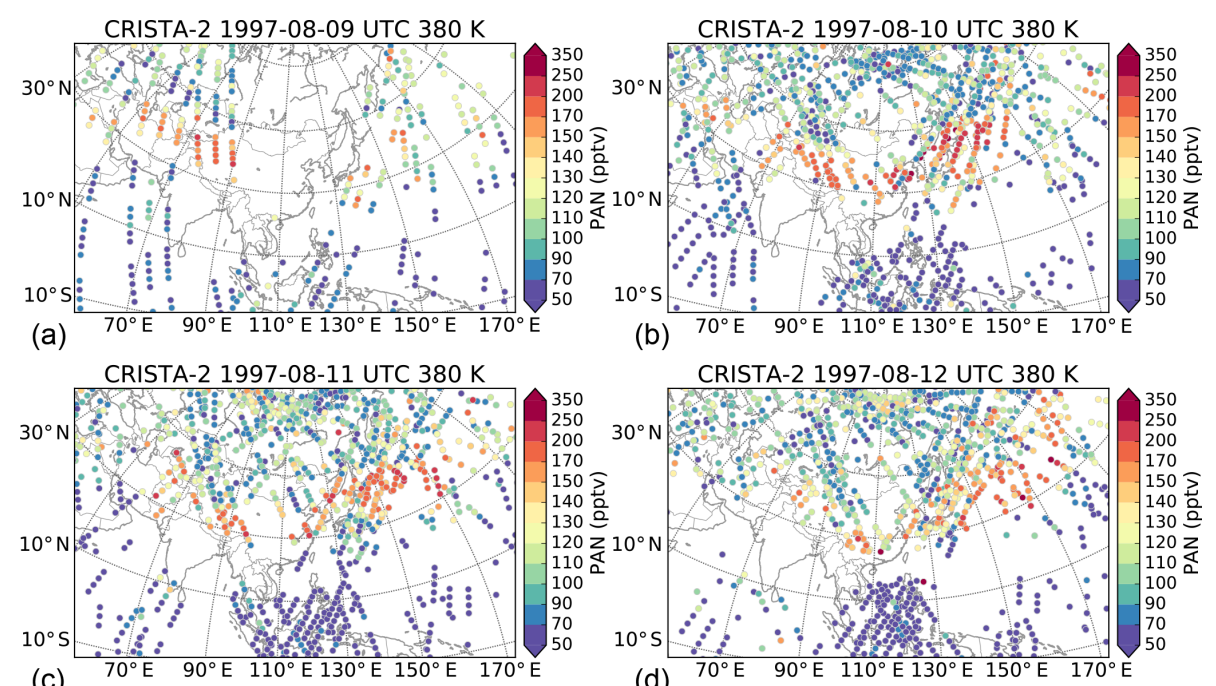

(c)

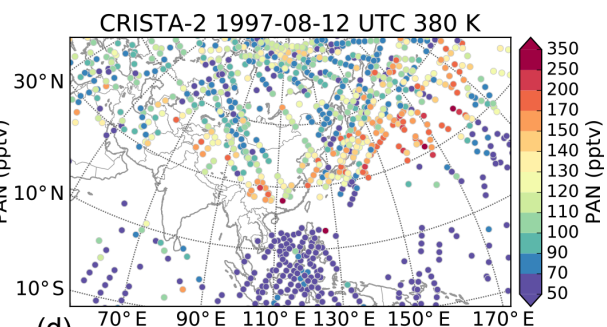

(d)

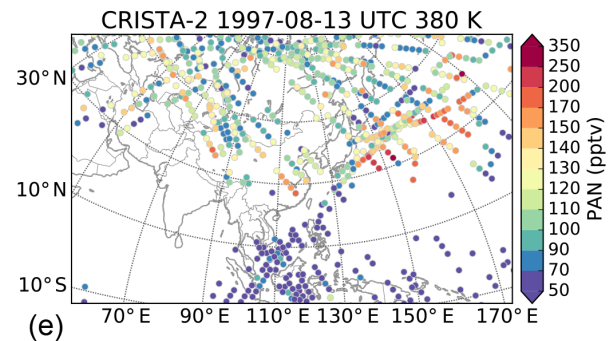

(e)

Figure 3. PAN derived from CRISTA-2 measurements on $380 \mathrm{~K}$. Retrieved PAN VMRs are interpolated vertically to $380 \mathrm{~K}$ within each derived profile and located at the horizontal position of the closest tangent point. Shown are all values of the indicated day.

the considered period, the approximate location of the ASM is over the Tibetan Plateau; subsequently, a large eddy is shed eastwards. Such smaller anticyclones typically break off several times from the main anticyclone during summer, even though westward propagating ones are more common (e.g. Dethof et al., 1999; Hsu and Plumb, 2000; Popovic and Plumb, 2001; Garny and Randel, 2013; Vogel et al., 2014). On 11 August 1997, a clear separation between air masses of the main anticyclone and of the smaller eastward propagating anticyclonic eddy can be observed, with a very faint connection in between. This eddy breaks off and continues moving towards the American coast while descending below the $100 \mathrm{hPa}$ pressure surface.

\subsection{Structures in derived trace gases}

We focus here on retrieved PAN volume mixing ratios (VMRs), as this trace gas has the best quality of the derived trace gases with respect to the characterisation of the ASM anticyclone. The positive water-vapour anomaly within the anticyclone has a much smaller gradient to stratospheric air at the same altitude, making it difficult to discern the gradient against the retrieval noise; the same is true for the chlorofluorocarbons. Ozone would also work as a negative anomaly highlighting tropospheric air, but it has sources in both the stratosphere and the polluted troposphere and has thus also a smaller gradient at the examined altitude levels. We revisit ozone at a later point, though (see below).

Figure 3 shows PAN measurements for the 5 consecutive days, offering the best measurement density in the UTLS, which is possible with the configuration of the CRISTA instrument. The measurement gaps over India and the Pacific are caused by high-altitude cloud systems that prevent the retrieval of trace gases from measured spectra at the shown altitudes. To remove cloud-affected spectra from the retrieval, the colour ratio between the radiances, which are averaged between 791.00 to $793.00 \mathrm{~cm}^{-1}$ and 832.30 to $834.40 \mathrm{~cm}^{-1}$, is determined and spectra with a ratio of less than 4 are discarded (Spang et al., 2012). In Fig. 3, the $380 \mathrm{~K}$ surface is shown, which typically is located rather high in the anticyclone. The spatial extent of the anticyclone can be identified using the horizontal gradient in the trace gases at this level (Ploeger et al., 2015).

In the extratropical stratosphere, PAN mixing ratios larger than 50 to $80 \mathrm{pptv}$ are not expected, but filaments with higher VMR may be found in the tropical troposphere and in the extratropical mixing layer. However, within the CRISTA2 measurements over Asia, the air masses with highly enhanced VMRs compared to the stratospheric background are solely found within the anticyclone of the ASM and the spunoff eddy. 

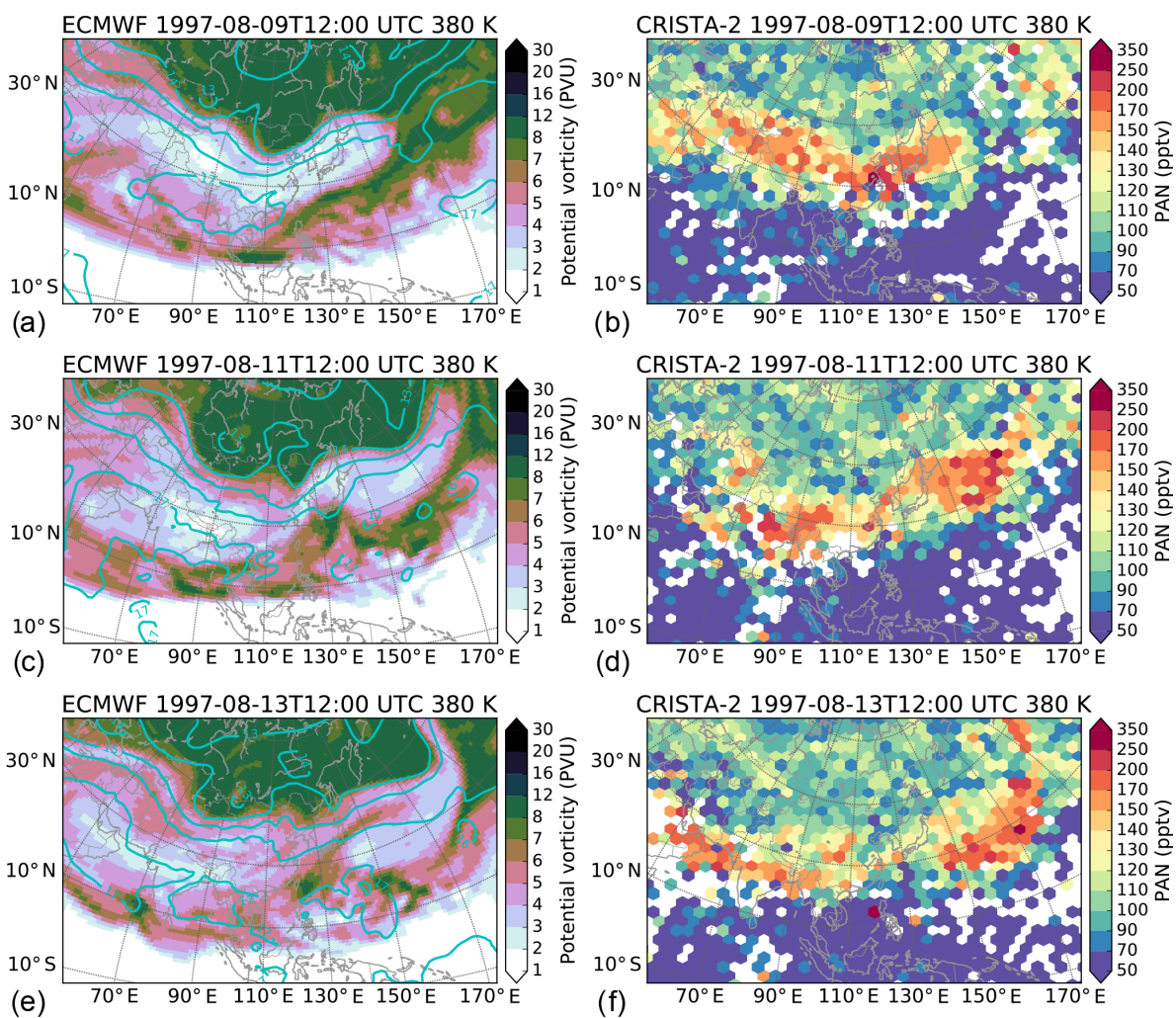

Figure 4. PAN derived from CRISTA-2 measurements and potential vorticity derived from ECMWF ERA-Interim model data on $380 \mathrm{~K}$. The cyan contour lines indicate geopotential altitude. The PAN panels show PAN VMRs for all CRISTA-2 measurements taken from 9 to 13 August 1997. The horizontal location is determined by means of trajectory calculations to the position that the air parcels have at the time indicated by the title of the figure.

The PAN VMR measurements in Fig. 3 plotted at their tangent points sketchily show the eddy-shedding event (compare to Fig. 2). Especially the weakening "connection" at $120^{\circ} \mathrm{E}$ is well covered by measurements on each day. On 10 August 1997, the main anticyclone and the forming eddy are still well connected. The connection progressively weakens until 13 August 1997, when the eddy is finally well separated by air masses with low PAN VMRs. Further note the elongated PAN filament stretching towards Alaska on 12 and 13 August.

PAN VMRs are assumed to be stable for a couple of days at the given altitudes and temperatures. Thus, the measurement density can be improved by synoptically interpolating the measurements of multiple days to a single point of time using trajectory calculations. For all air parcels measured by the CRISTA-2 instrument from 9 to 13 August 1997, forward and backward trajectories were computed using the CLaMS trajectory model from the time of measurement to 12:00 UTC of each day. Using these trajectories, one can project all measured air parcels to noon of any given day and thereby it is possible to obtain a coherent and more complete picture of the synoptic situation. Figure 4 shows PV and synoptically calculated PAN data on $380 \mathrm{~K}$ poten- tial temperature combined from all measurements. Comparing Fig. 3 with Fig. 4 shows that the trajectory-based fillin makes the prevalent structures more apparent. The negative anomalies in PV agree very well with the positive PAN anomalies and the highest PAN VMRs at this altitude clearly occur for PV values of 3 PVU or less. The sharpest PV gradient occurs towards the northern sub-tropics in agreement with a sharp drop of PAN VMRs towards the extratropical lowermost stratosphere to the north. The PV gradient in the southern part of the anticyclone is less pronounced and the structures in PAN VMRs are correspondingly less distinct. Only further south does clean tropical air streaming in from the Pacific exhibit PAN VMRs below 50 pptv.

The eddy-shedding event can be seen well in both PV and PAN VMRs. Even the fine filamentary structure between the anticyclone and the spun-off eddy can be distinguished in retrieved PAN VMRs. We thus conclude that PAN is an excellent tracer to identify anticyclone air in the given time frame (see also Fadnavis et al., 2014).

Using trajectories for the synoptic interpolation introduces an additional uncertainty to the data due to the uncertainties of available wind data. Even though this uncertainty is small for the analysed altitude range and timescale of about 1 week, 


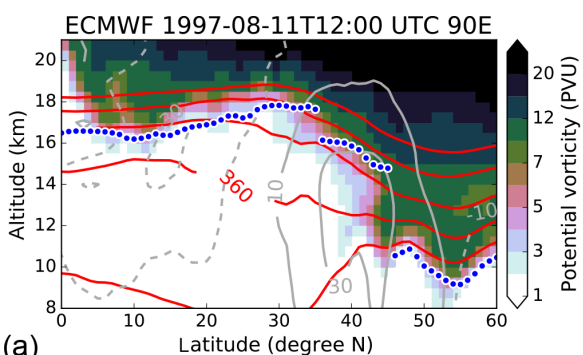

(a)

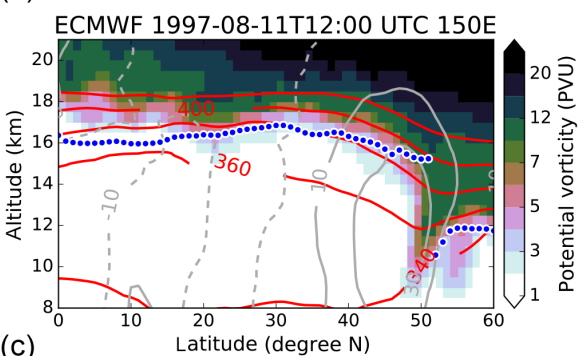

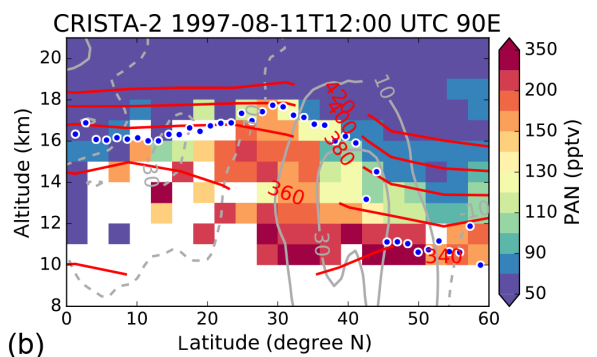

(b)

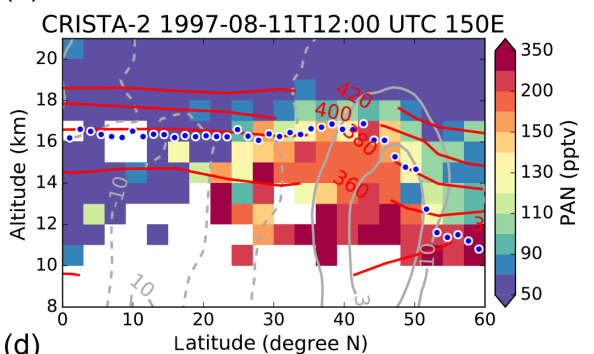

Figure 5. Vertical cross sections along $90^{\circ} \mathrm{E}$ and $150^{\circ} \mathrm{E}$. Panels (a, c) show potential vorticity with isentropes (red; K), winds (grey; m s ${ }^{-1}$ ), and the primary thermal tropopause (blue dots) based on ERA-Interim data. Panels (b, d) show CRISTA PAN VMRs with CRISTA isentropes (red; K), ERA-Interim winds (grey; $\mathrm{m} \mathrm{s}^{-1}$ ), and CRISTA primary thermal tropopause (blue dots). The CRISTA data were averaged over $\pm 5^{\circ}$ longitude and missing pixels were horizontally interpolated to compute the CRISTA isentropes.

we minimise its impact by choosing the midpoint of the measurement period, 12:00 UTC on 11 August 1997, for further analysis in order to reduce the time over which trajectories need to be computed to less than $36 \mathrm{~h}$ on average.

\subsection{Horizontal and vertical confinement}

Figure 5 shows two vertical cross sections through the potential vorticity field: one through the main anticyclone (Fig. 5a) and one through the eddy (Fig. 5c). For both PV and PAN anomalies, the northern boundary is formed by the jet stream with strong winds of more than $30 \mathrm{~m} \mathrm{~s}^{-1}$, followed by a sharp increase in PV and lower PAN VMRs north of the subtropical westerly jet.

In Fig. $5 \mathrm{~b}$ at $90^{\circ} \mathrm{E}$, the thermal tropopause seems to provide a good transport barrier, or proxy thereof, for the positive PAN anomaly at tropical latitudes. While the isentropic levels crossing the thermal tropopause would principally allow for the transport of PAN into the stratosphere, the westerly and easterly jets inhibit this transport. Still, on the extratropical side northward of $40^{\circ} \mathrm{N}$, PAN VMRs are found to be elevated by $\approx 20$ to $40 \mathrm{pptv}$ for $\approx 3 \mathrm{~km}$ above the thermal tropopause, indicating transport of polluted tropospheric air into the extratropical lowermost stratosphere, which may have entered this extratropical transition layer (exTL) during breaking Rossby waves or an eddy-shedding event.

In the given situation, isentropic surfaces below $370 \mathrm{~K}$ do not cross the thermal tropopause on the southern side of the ASM and remain at low PV values down to the Equator. The tropical easterly jet also poses a horizontal transport barrier but at a more southern position and not discernible by the
PV criterion, which only works at higher latitudes. Measurements of PAN at $360 \mathrm{~K}$ show a strong contrast of clean air south of the tropical easterly jet and polluted air north of it within the ASM.

A different situation is given in the eddy in Fig. 5d, where elevated PAN VMRs can be found for $\approx 1 \mathrm{~km}$ above the tropical thermal tropopause; however, the altitudes and potential temperatures at which the PAN anomaly is found are still similar to the main anticyclone. This may indicate horizontal transport of tropospheric air into the lowermost stratosphere across the thermal tropopause upon leaving the area of elevated pressure over India (see geopotential altitude in Fig. 2). Alternatively, the descending thermal tropopause may become more permeable and start forming a transition layer like in the extratropics.

The relationship between PV and PAN VMRs can be further explored by comparing typical PAN VMRs for each value of PV. Figure 6a shows a scatter plot of potential temperature of measured air parcels against PV with PAN VMRs overlaid as colour code. Deriving a criterion for the extent of the ASM based on PV is advantageous for analysing the ASM in, for example, ECMWF model data. There is a general gradient from high PAN VMRs at low potential temperature values towards low PAN VMRs at high potential temperature values as is expected for a tropospheric pollutant. However, the area between 360 and $400 \mathrm{~K}$ has an additional horizontal structure that is related to the ASM anticyclone. To derive further information from the noisy, unstructured data, a smooth 2-D surface on a regular grid is fitted against the data. A fine regular grid is defined in potential temperature and modified PV. Modified PV $\left(\mathrm{PV}_{\text {mod }}=\right.$ 


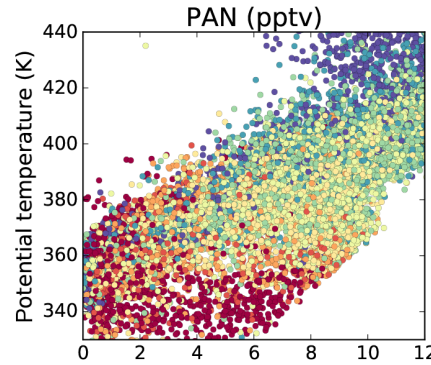

(a)

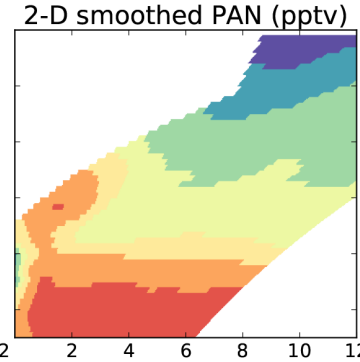

(b)

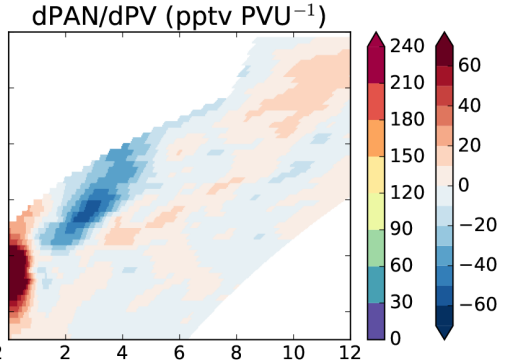

(c)

Figure 6. Potential temperature versus PV with colour-coded PAN VMR (gradients). Panel (a) shows measured potential temperature against PV with colour-coded PAN VMR for all air parcels between 20 and $240^{\circ} \mathrm{E}$, between 10 and $60^{\circ} \mathrm{N}$, and below $460 \mathrm{~K}$; these are all air parcels from the approximate location of the ASM and its surroundings. Panel (b) shows the fit of a smooth 2-D surface to the available data (the $5 \%$ most mis-fitting air parcels were removed in a first step; the surface is restricted to the area defined by measurements). Panel (c) shows the derivative of the smoothed PAN VMRs with respect to PV.

$\left.\mathrm{PV} \cdot(\theta / 380 \mathrm{~K})^{-4.5}\right)$ is a scaled form of PV that partially reduces its dependency on potential temperature (Lait, 1994; Müller and Günther, 2003) and thereby transforms the covered potential temperature-PV space into a more rectangular region (the choice of the exponent is not very important for this purpose). The PAN VMR values on the grid are then determined by least-squares minimisation against the measured data with additional smoothness constraints on the first derivative with respect to potential temperature and the second derivative with respect to modified PV. The strength of the constraints somewhat influences the derived absolute values, but the shape and the position of the maxima are robust.

The result is shown in Fig. 6b. One can discern the general decrease of PAN VMRs with potential temperature. Horizontally, two features are notable. For low PV values at $350 \mathrm{~K}$ a negative PAN anomaly can be seen, which is caused by the inclusion of clean tropical air southwards of the easterly jet. More important is the decrease of PAN VMRs from about 370 to $390 \mathrm{~K}$, which is indicative of the uplift and confinement of PAN-rich air masses within the ASM anticyclone.

The derivative of PAN VMRs with respect to PV is then depicted in Fig. 6c. The derivative highlights the change in PAN VMRs across the dynamical tropopause. The PV value, at which PAN has the strongest gradient, increases linearly with potential temperature from $360 \mathrm{~K}$ up to the thermal tropopause level. This plot enables the visualisation of the confinement of the ASM anticyclone and shows which air masses are entrapped within. The position of the transport barrier can be easily discerned by the negative anomaly in Fig. 6c.

Figure 7 shows that the decrease of PAN VMRs for increasing PV is strongest between 370 and $375 \mathrm{~K}$, with a maximum decrease of $\approx-60 \mathrm{pptv} P V U^{-1}$ at $\approx 2 \mathrm{PVU}$. On the $380 \mathrm{~K}$ isentropic surface, the maximal gradient is given by $\approx-44 \mathrm{pptv} \mathrm{PVU}^{-1}$ at $\approx 3.2 \mathrm{PVU}$. This is consistent with the study of Ploeger et al. (2015), where a similar comparison for modelled $\mathrm{CO}$ and PV exhibited peak gradients between 2.6 and 4.6 PVU for the years of 2011 to 2013. It is plausible that a value between 2 and 6 PVU is found for the negative anomaly in gradient because PV values in this range are also commonly chosen for the dynamical tropopause (e.g. Kunz et al., 2011). Kunz et al. (2011) also found that a value of $\approx 4 \mathrm{PVU}$ agrees quite well with the thermal tropopause in summer on the Northern Hemisphere.

The $380 \mathrm{~K}$ isentropic surface is well suited in the given meteorological situation to describe the confinement of the polluted air masses of the Asian monsoon. The gradient dPAN/dPV for $380 \mathrm{~K}$ shown in Fig. 7 can be used to choose a suitable value of PV to determine the boundary of the ASM. For values above $5 \mathrm{PVU}$ at $380 \mathrm{~K}$, the gradient is (effectively) zero, so it notifies air outside the ASM. The maximum gradient at this isentropic level is given at 3.2 PVU, which notifies the largest change of VMR with PV, so it should be right within the mixing layer. One might look at the maximum of the second derivative to identify the point of strongest curvature, but we found the computation of this to be numerically unstable. However, this maximum of the second derivative must be located between the maximum value of the first derivative and 5 PVU, where the first derivative becomes constant. Instead we pick the value of $4.1 \mathrm{PVU}$, the midpoint of 3.2 and 5.0 PVU.

In Fig. 8, we thus again consider the PAN distribution on the $380 \mathrm{~K}$ surface. The PV isoline for 4.1 PVU agrees quite well with the positive PAN VMR anomaly. Small changes of the chosen PV value (in the order of \pm 0.2 ) do not change the agreement significantly.

Figure 8 shows also the location of the primary thermal tropopause derived from CRISTA temperature data. The thermal tropopause is determined according to the World Meteorological Organization (WMO) criterion (WMO, 1957). We first compute the lapse rate between derived temperature values and assign these lapse rates to the altitude of the midpoint of the interval. We then locate the altitude, where the lapse rate falls below $2 \mathrm{~K} \mathrm{~km}^{-1}$, by linear interpolation, which gives a better result (also for model data) than simply assigning the tropopause altitude to the altitude of 


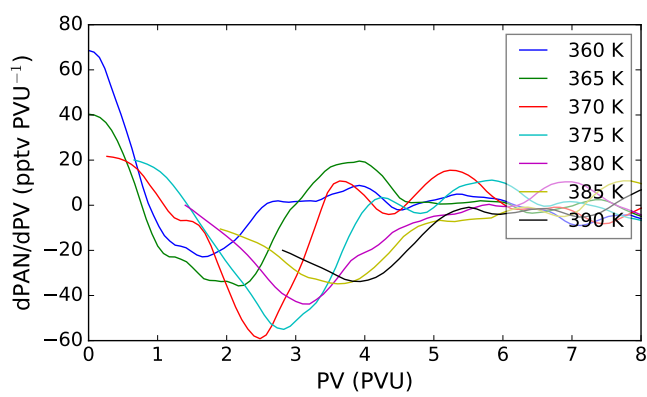

Figure 7. Derivative of smoothed PAN VMRs with respect to PV against $\mathrm{PV}$, computed for all air parcels between 20 and $240^{\circ} \mathrm{E}$, between 10 and $60^{\circ} \mathrm{N}$, and below $460 \mathrm{~K}$ for selected isentropic levels (see also Fig. 6c).

an available measurement point. Montgomery stream function isolines are also given in Fig. 8 and indicate the direction and speed of the geostrophic wind (the wind follows the isolines and is faster where they are closer together). The wind approximately follows the thermal tropopause isoline and reaches its maximum at the thermal tropopause location except for the region between the ASM anticyclone and the shed eddy.

For the ASM anticyclone, the 4.1 PVU isoline agrees well with the extent of the PAN anomaly. In contrast, the thermal tropopause seems to be shifted northward. On the northern side the thermal tropopause agrees well with the maximum in wind speed. Here, the air in the jet stream seems to consist mostly of non-ASM air brought along in the subtropical westerly jet. The discrepancy on the southern side may be caused by an insufficient amount of measurement data due to the high convective clouds over India.

A different picture is given for the shed eddy in the east. Here, the thermal tropopause agrees better with the extent of the PAN anomaly compared to the ASM anticyclone. On the northern side, the thermal tropopause and the 4.1 PVU isoline coincide. The PAN anomaly extends into the subtropical jet, which results in an elongated streamer pulled along the jet stream visible also in Fig. 4f. On its southern side, the thermal tropopause seems to fit slightly better to the PAN anomaly than the 4.1 PVU isoline. The small region in the centre connects the anticyclone with the eddy. Only the 4.1 PVU isoline closely follows the high PAN VMRs in this region.

Another way of identifying the extent of confinement is by transferring the geolocated measurement data into tracertracer space (e.g. Hintsa et al., 1998). As noted, PAN is a mostly tropospheric gas without stratospheric sources, and its stratospheric lifetime is too short to accumulate there to larger VMR values. It is therefore possible to identify tropospheric air masses by large VMRs of PAN. Using another trace gas such as ozone that exhibits large VMRs only in the stratosphere, one may identify the association of an air parcel with either the troposphere or the stratosphere solely

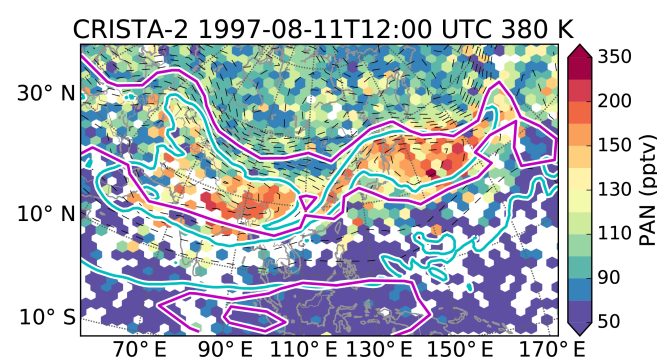

Figure 8. CRISTA PAN VMRs on $380 \mathrm{~K}$. The PAN VMRs are as in Fig. 3d. Additionally shown are Montgomery stream function isolines (dashed black), potential vorticity isoline (based on ERAInterim) for 4.1 PVU (cyan), and the location of the CRISTA primary thermal tropopause (magenta).

by the VMRs of the two trace gases. Using CRISTA-2 derived $\mathrm{O}_{3}$ values, one derives ideally an L-like shape in the UTLS region (e.g. Hoor et al., 2002; Pan et al., 2007; Park et al., 2007) such as shown in Fig. 9a. Depicted are measured air parcels from 10 to $80^{\circ} \mathrm{N}$, from 20 to $210^{\circ} \mathrm{E}$, and with a distance of less than $5 \mathrm{~km}$ from the thermal tropopause. One line of the $\mathrm{L}$ is thereby formed by air parcels of tropospheric characteristics, while the other is formed by air parcels of stratospheric characteristics. Air parcels not falling on one of the branches are then assumed to be generated by mixing between the "pure" branches. The stratospheric branch is well visible in Fig. 9 with high $\mathrm{O}_{3}$ VMRs and correspondingly low PAN VMRs. The tropospheric branch is less pronounced, probably because the highest PAN VMRs can be found close to the tropopause in contrast to $\mathrm{O}_{3}$, where the highest VMRs can be found significantly above. Mixing between tropospheric and stratospheric air introduces socalled mixing lines, which are air parcels that lie on lines between the two branches. Analysing the position of the measured air parcels in the tracer-tracer space shows no apparent mixing lines for air parcels with an $\mathrm{O}_{3} \mathrm{VMR}$ of more than 1.0 ppmv. This indicates that no STE occurs for these air parcels. To identify the thresholds for separating the tropospheric/stratospheric branches from the "mixing region", we performed a linear regression. To analyse the stratospheric branch, we first selected all measured air parcels in the region of the ASM (from 10 to $80^{\circ} \mathrm{N}$ and from 20 to $210^{\circ} \mathrm{E}$, located between the thermal tropopause and $5 \mathrm{~km}$ above, and with an $\mathrm{O}_{3}$ VMR of less than $1 \mathrm{ppmv}$ to exclude air parcels from the overworld). Using a linear regression, we identified a linear relationship for the middleworld between PAN and $\mathrm{O}_{3}$ VMRs of PAN $\left[\mathrm{molmol}^{-1}\right]=1.11 \times$ $10^{-10} \mathrm{~mol} \mathrm{~mol}^{-1}-0.7 \times 10^{-5} \mathrm{O}_{3}\left[\mathrm{~mol} \mathrm{~mol}^{-1}\right]$. The residuals show a $1 \sigma$ uncertainty of $\approx 34 \mathrm{pptv}$, which we added to the linear fit to determine the threshold as shown in Fig. 9a. A similar analysis of the tropospheric branch gave a relationship of $\mathrm{O}_{3}\left[\mathrm{~mol} \mathrm{~mol}^{-1}\right]=1.24 \times 10^{-7} \mathrm{~mol} \mathrm{~mol}^{-1}-9.0 \times$ $10^{7} \mathrm{PAN}\left[\mathrm{mol} \mathrm{mol}^{-1}\right]$ with $\sigma \approx 0.06 \mathrm{ppmv}$. The threshold for $\mathrm{O}_{3}$ is quite high, which may be caused by pollution in the 

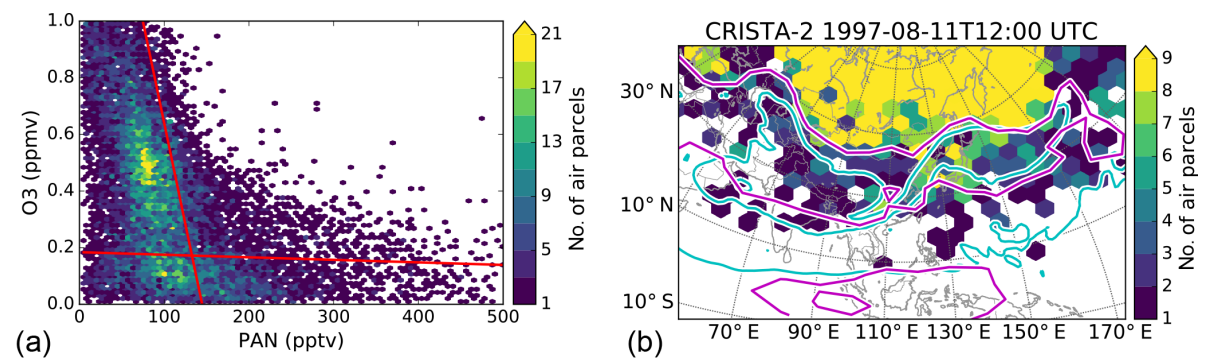

Figure 9. Panel (a) shows the relationship between PAN and $\mathrm{O}_{3}$ for measured air parcels from 10 to $80^{\circ} \mathrm{N}$, from 20 to $210^{\circ} \mathrm{E}$, and with a distance of less than $5 \mathrm{~km}$ from the thermal tropopause. Two red lines have been drawn at PAN $\left[\mathrm{mol} \mathrm{mol}^{-1}\right]=1.45 \times 10^{-10} \mathrm{~mol} \mathrm{~mol}^{-1}-$ $0.7 \times 10^{-5} \mathrm{O}_{3}\left[\mathrm{~mol} \mathrm{~mol}^{-1}\right]$ and at $\mathrm{O}_{3}\left[\mathrm{~mol} \mathrm{~mol}^{-1}\right]=1.84 \times 10^{-7} \mathrm{~mol} \mathrm{~mol}^{-1}-9.0 \times 10^{7} \mathrm{PAN}\left[\mathrm{mol} \mathrm{mol}^{-1}\right]$ to roughly mark stratospheric (left) and tropospheric (bottom) branches. Panel (b) shows the total number of air parcels in the same geographic region and altitude range, where $\mathrm{O}_{3}$ is less than 1 ppmv and located in the upper right "quadrant" of (a). The cyan and magenta isolines are the same as in Fig. 8 to facilitate the comparison of structures with Fig. 9.

Asian monsoon. The air parcels in the lower left quadrant with lower $\mathrm{O}_{3}$ VMRs are found in the tropical troposphere and were advected from the Pacific region and are thus likely devoid of Asian pollution. The presented results are not sensitive to small variations of the threshold.

Having thus identified chemically tropospheric and stratospheric air masses, one may associate air parcels with both elevated PAN and $\mathrm{O}_{3}$ with the mixing layer of the UTLS. Figure $9 \mathrm{~b}$ shows the number of the mixed air parcels projected by trajectories to 12:00 UTC on 11 August 2011. The number of such parcels (which effectively relates to the thickness of the exTL) is largest in the extratropical UTLS that is located roughly northward of the westerly jet stream on $380 \mathrm{~K}$. Most of these air parcels are located between 10 and $14 \mathrm{~km}$. The anticyclone has very few such air parcels, whereas the shed eddy and especially the small remaining connection between the anticyclone and the eddy exhibit a larger number as expected from the previous results. This is further evidence that the anticyclone confines its air masses quite well and that mixing occurs during the eddy-shedding process or within the newly shed eddy.

\subsection{Source regions}

The question remains, where and when the measured PAN originates that is found below the thermal tropopause and if it truly functions as a tracer of anticyclone air. To work as a tracer, it needs to originate from within the Asian monsoon region. Using the CLaMS model, we calculated backward trajectories for all air parcels using ERA-Interim wind data. As criteria for air originating from the core of the anticyclone, we selected only air parcels with a PV value less than 3.7 PVU, a PAN VMR of greater than $150 \mathrm{pptv}$, and a potential temperature greater than $360 \mathrm{~K}$. The latter restriction is necessary to exclude polluted air from the subtropics. Figure 10a shows the horizontal location of selected air parcels, which aligns well with the area of high PAN VMRs on $380 \mathrm{~K}$ shown in Fig. 8.
Following the trajectories of the selected air parcels backwards in time, we stopped the calculation as soon as the altitude of the air parcel fell below $10 \mathrm{~km}$ altitude - the results are, however, qualitatively similar for different thresholds such as $5 \mathrm{~km}$ altitude. Almost all air parcels fell below the threshold altitude in the preceding 2 months. Figure $10 \mathrm{~b}$ shows the locations, where the back-tracked air parcels crossed the $10 \mathrm{~km}$ threshold. We find that the majority of parcels can be traced back to the southern slopes of the Himalaya. Obviously, this defines only the entry point into the upper circulation of the ASM, not necessarily the point of origin on ground level.

Another set of air parcels with a PV value less than 3.7 PVU, a PAN VMR of now less than 100 pptv, and a potential temperature greater than $360 \mathrm{~K}$ was also followed back in time. Those stem largely from the Pacific region, which is seemingly a source region for clean air entering the ASM anticyclone.

This is consistent with a more comprehensive trajectory study by Bergman et al. (2013) and the CLaMS 3-D simulations using tracers of air mass origin by Vogel et al. (2015), who also found that most of the air within the anticyclone stems from within India and China with a smaller portion originating in the Pacific.

The trajectories also allow an identification of the point in time at which the air masses left the boundary layer to be drawn upwards into the anticyclone. Figure 11 shows the number of air parcels that passed the $10 \mathrm{~km}$ threshold on the given day. Most air parcels left the boundary layer between 20 June and 14 July. Inspecting, for example, the synoptic situation for the peak of transition events visible for 10 July shows that the updraught captured in ERA-Interim reanalysis data seems to be caused by south-westerly winds blowing against the slope of the Himalaya. This implies that, even though the entry point into the upper ASM is well confined, most air originates from the boundary layer located southwards. However, as convection is likely a major mechanism for transporting air into the upper troposphere, a mechanism 

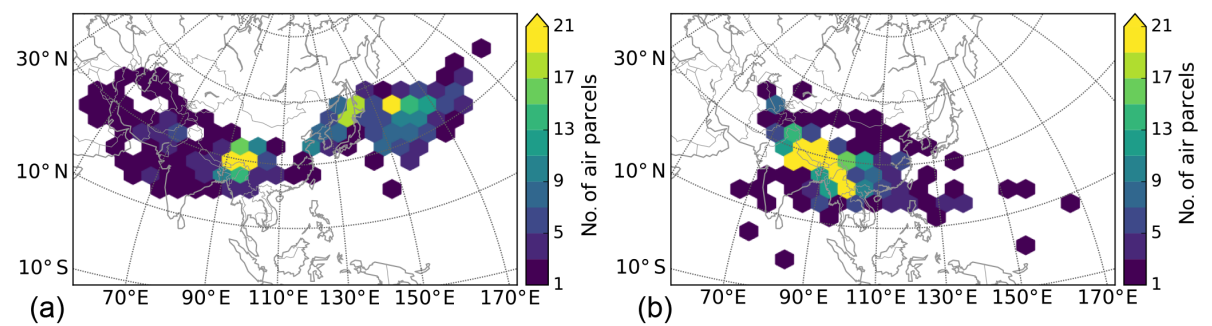

Figure 10. Panel (a) shows the number and horizontal location of all 454 air parcels with PV less than 3.7, PAN VMR greater than 150 pptv, and potential temperature greater than $360 \mathrm{~K}$ on 11 August 2011. Panel (b) shows the number and horizontal location of the subset of 448 air parcels, where the backward trajectories fell below $10 \mathrm{~km}$ altitude.

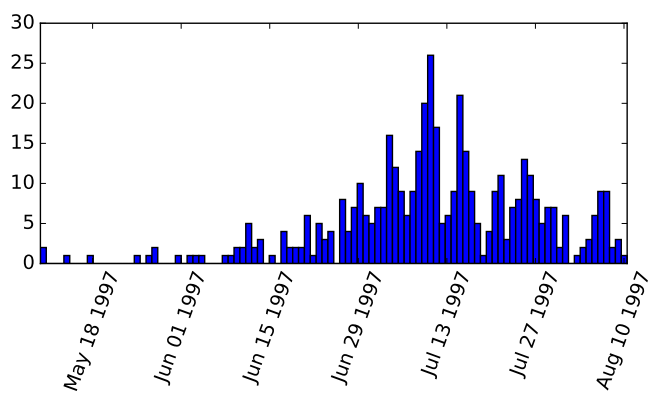

Figure 11. Histogram showing the point in time when the air parcels of Fig. 10 fell below $10 \mathrm{~km}$ altitude.

that is not well captured in 6-hourly ECMWF reanalysis data, the question remains whether the air could origin from other sources over Asia apart from the small identified source region.

However, the back trajectories do not reveal significant sources outside the ASM region so that we assume that the majority of measured PAN stems from polluted air from the Indian subcontinent.

\section{Discussion and conclusions}

This study presented a highly resolved snapshot of PAN and $\mathrm{O}_{3}$ VMRs in the ASM during the second week of August 1997. The CRISTA-2 dataset represents the first highresolution global coverage of PAN in the UTLS and perhaps the currently best available snapshot of the ASM.

The observations show the ASM anticyclone and the shedding of a large eddy to the east. We could demonstrate that the air confined within the anticyclone and the eddy was highly polluted as indicated by increased PAN VMRs measured by CRISTA. The PAN anomaly matched very well to PV values taken from ERA-Interim reanalysis data. We examined the relationship between PAN and PV as a function of potential temperature and that there is a particular PV value for each potential temperature level, where the decrease in PAN VMR is maximal. These PV values of strong PAN gradients increase with potential temperature up to the highest potential temperature found in the measured data. This demonstrates that PAN is enhanced within the anticyclone and the eddy compared to the stratospheric background and can therefore act well as a marker of anticyclone air. The distribution of measured PAN indicates that air masses are strongly confined within the ASM anticyclone consistent with previous model studies and less well-resolved satellite observations (e.g. Park et al., 2007). We demonstrated that for the given situation, the location of the thermal tropopause on an isentropic surface was a useful marker for the extent of anticyclone air, even though the area of the anticyclone was overestimated. This indicates that the thermal tropopause constitutes a strong transport barrier against vertical and also for isentropic transport within the uppermost part of the ASM anticyclone into the lowermost stratosphere. A potentially better marker was a PV value of 4.1 PVU that was computed from the first derivative of PAN with respect to PV. While the agreement with the extent of the PAN anomaly was better, the threshold value can only be determined with significant uncertainty and it is not clear how the results gained here may be generalised.

We further analysed the relationship between PAN and $\mathrm{O}_{3}$ to identify the extent of mixing at the edges of the anticyclone and the eddy. As demonstrated, PAN can be used as a tracer for chemically tropospheric air, while $\mathrm{O}_{3}$ functions as a tracer for chemically stratospheric air. Mapping all retrieved air parcels into tracer-tracer space allowed air parcels to be identified that are chemically a mixture of both stratospheric and tropospheric air. Transferring these results from tracer-tracer space back into the geospatial space allowed the identification of the regions, where the most "mixed" air parcels were observed. While only very few of such air parcels could be observed in the core of the anticyclone, many such air parcels were present in the region between the eddy and the anticyclone. The presented vertical cross sections (Fig. 5) show air masses with a mixture of chemically tropospheric and stratospheric air above the thermal tropopause of the eddy. This suggests that the mechanism of eddy shedding might be an exceptionally quick pathway for STE, where air previously confined of the ASM anticyclone may enter the UTLS mixing layer within days. 
The sources of the PAN anomaly were identified by means of backward-trajectory simulations. Most of the polluted air enters the anticyclone above the southern slopes of the Himalaya, being uplifted when south-westerly winds blow against the mountains. In contrast, clean air parcels could largely be traced back towards the Pacific warm pool.

The presented data serve well as an example for the capabilities of highly resolving limb-sounding instruments for the study of dynamic phenomena. Further insights could be gained by a better coverage in time (while retaining the same number of measurements within $24 \mathrm{~h}$ ) and with a better vertical sampling in the UTLS, which would be feasible with a next-generation infrared limb imager (e.g. Riese et al., 2005).

\section{Data availability}

The used ERA-Interim data can be retrieved from ECMWF Web API (https://software.ecmwf.int/wiki/display/ WEBAPI/Access+ECMWF+Public+Datasets; ECMWF, 2011). The temperatures and trace gas volume mixing ratios derived from the CRISTA-2 experiment are available as supplement. 


\section{Appendix A: Retrieval}

This appendix describes the level 2 processing used to derive the trace gas data used in this paper. It is not based on previous CRISTA-2 processing but rather derived from the level 2 processor used for the air-borne successor instrument CRISTA-NF described by Ungermann et al. (2013) with some necessary changes to accommodate to the different measurement mode of the satellite mission and differences in the available level 1 data (calibrated spectra). For the sake of completeness, we give here a full overview.

Deriving trace gases from measured radiances poses a socalled inverse problem. Knowing the radiative transfer equations and the state of the atmosphere, it is straightforward to compute emitted and absorbed infrared radiation with a spectral simulation code. It is, however, more difficult to discern the state of the atmosphere from measured radiances. This problem is an ill-posed problem, as no solution may exist due to measurement errors of the instrument, it may not be unique, and it may vary greatly with measurement noise. As such, it is typically not possible to identify the correct atmospheric state that generated the measured spectra.

Instead, one approximates the ill-posed exact problem by a well-posed approximate one that incorporates a priori knowledge about the solution, which - for limb sounders - usually consists of smoothness criteria to prevent unnatural oscillations in the resulting trace gas profiles. Also, one does not require an exact reproduction of the measured spectra but allows for deviations of the order of the expected noise to compensate for the measurement errors. Mathematically, the problem is reformulated as a minimisation problem. Let $\boldsymbol{F}: \mathbb{R}^{n} \longmapsto \mathbb{R}^{m}$ be the forward model that maps a discretised atmospheric state $\boldsymbol{x} \in \mathbb{R}^{n}$ to the set of all evaluated radiance measurements of one profile $\boldsymbol{y} \in \mathbb{R}^{m}$. Then the solution $\boldsymbol{x}_{\mathrm{f}}$ is defined by the minimum of the cost function

$$
\begin{aligned}
J(\boldsymbol{x}) & =(\boldsymbol{F}(\boldsymbol{x})-\boldsymbol{y})^{\mathrm{T}} \mathbf{S}_{\epsilon}^{-1}(\boldsymbol{F}(\boldsymbol{x})-\boldsymbol{y}) \\
& +\left(\boldsymbol{x}-\boldsymbol{x}_{\mathrm{a}}\right)^{\mathrm{T}} \mathbf{S}_{\mathrm{a}}^{-1}\left(\boldsymbol{x}-\boldsymbol{x}_{\mathrm{a}}\right) .
\end{aligned}
$$

The matrix $\mathbf{S}_{\epsilon} \in \mathbb{R}^{m \times m}$ approximates the true measurement error covariance matrix of the instrument, which here is constructed as a simple diagonal matrix with a relative error of $1 \%$. The matrix $\mathbf{S}_{\mathrm{a}}^{-1} \in \mathbb{R}^{n \times n}$ together with the vector $\boldsymbol{x}_{\boldsymbol{a}} \in$ $\mathbb{R}^{n}$ defines the a priori knowledge of the atmosphere. The a priori values for pressure, temperature, and water vapour are taken from ECMWF ERA-Interim data, PAN assumes a zero profile, while the remaining entities are taken from the Remedios et al. (2007) climatology. The matrix $\mathbf{S}_{\mathrm{a}}$ is assembled as the sum of a matrix with the variances of the atmospheric quantities on the diagonal and a first-order Tikhonov regularisation matrix (Tikhonov and Arsenin, 1977), which in effect computes the $L^{2}$-norm of the first derivative approximated by finite differences, again scaled with the variance. To reduce the bias introduced by this regularisation we scale the zeroth-order matrix with a factor of 0.1 . The correlation
Table A1. A list of used correlation length for regularisation.

\begin{tabular}{lr}
\hline Target & $\begin{array}{r}\text { Correlation } \\
\text { length }(\mathrm{km})\end{array}$ \\
\hline Temperature & 2 \\
$\mathrm{CCl}_{4}$ & 2 \\
$\mathrm{ClONO}_{2}$ & 8 \\
$\mathrm{CFC}-11$ & 2 \\
$\mathrm{CFC}-113$ & 8 \\
$\mathrm{HCFC}-22$ & 8 \\
$\mathrm{H}_{2} \mathrm{O}$ & 2 \\
$\mathrm{O}_{3}$ & 32 \\
$\mathrm{PAN}$ & 0.1 \\
\hline
\end{tabular}

Table A2. A list of employed integrated microwindows (IMW) and their spectral range.

\begin{tabular}{rcrl}
\hline IMW & Range $\left(\mathrm{cm}^{-1}\right)$ & IMW & Range $\left(\mathrm{cm}^{-1}\right)$ \\
\hline 0 & $777.35-778.75$ & 6 & $796.95-797.65$ \\
1 & $784.00-785.05$ & 7 & $808.15-809.55$ \\
2 & $787.15-790.95$ & 8 & $809.90-813.05$ \\
3 & $791.35-791.70$ & 9 & $820.40-821.45$ \\
4 & $794.15-794.85$ & 10 & $834.75-835.45$ \\
5 & $795.55-796.60$ & 11 & $844.90-849.10$ \\
\hline
\end{tabular}

lengths employed for the regularisation are summarised in Table A1.

The simulation uses the microwindows of Table $\mathrm{A} 2$ and takes the trace gases $\mathrm{C}_{2} \mathrm{H}_{6}, \mathrm{CCl}_{4}, \mathrm{ClONO}_{2}, \mathrm{CO}_{2}, \mathrm{CFC}$ 11, CFC-12, HCFC-22, CFC-113, CFC-114, $\mathrm{H}_{2} \mathrm{O}, \mathrm{HNO}_{3}$, $\mathrm{HNO}_{4}, \mathrm{NH}_{3}, \mathrm{~N}_{2} \mathrm{O}_{5}, \mathrm{NO}_{2}, \mathrm{O}_{3}, \mathrm{OCS}$, and PAN into account. Target quantities are temperature, $\mathrm{CCl}_{4}, \mathrm{CFC}-11$, HCFC-22, CFC-113, $\mathrm{ClONO}_{2}, \mathrm{H}_{2} \mathrm{O}, \mathrm{O}_{3}, \mathrm{PAN}$, and an aerosol background. We assume that the pressure is modelled well enough by ECMWF in the altitude region relevant for this paper, such that the error is negligible (for error estimates, we assume an error of $1 \%$ ).

The inversion itself employs the JURASSIC2 model as the forward model and the JUTIL inversion library for the minimisation of the cost function. While the given problems are of much smaller size than tomographic ones usually treated with this code (e.g. Kaufmann et al., 2015), the employed algorithms are still efficient. JURASSIC2 and JUTIL use a combination of $\mathrm{C}++$ and Python to combine optimal efficiency with a high adaptability. JUTIL minimises the cost function with a truncated conjugate-gradient trust-region method that leverages the inherent regularisation properties (Hanke, 1995) of the conjugate gradient method to improve the convergence speed. Retrieving one profile requires $\approx 60 \mathrm{~s}$ including the computation of diagnostic information such as errors due to various sources and resolution for typically six iterations of the minimiser on one core. 


\section{The Supplement related to this article is available online at doi:10.5194/acp-16-8389-2016-supplement.}

Acknowledgements. We sincerely thank A. Dudhia, of the University of Oxford, for providing the Reference Forward Model (RFM) used to calculate the optical path tables required by our forward model. The European Centre for Medium-range Weather Forecasts (ECMWF) is acknowledged for meteorological data support. This work was supported in part by the European Commission under grant number StratoClim-603557-FP7-ENV.2013.6.1-2. The CRISTA experiment was funded by the Bundesministerium für Bildung und Forschung (BMBF, Berlin) through the Deutsches Zentrum für Luft- und Raumfahrt (DLR, Bonn).

The article processing charges for this open-access

publication were covered by a Research

Centre of the Helmholtz Association.

Edited by: M. Chipperfield

\section{References}

Bergman, J. W., Fierli, F., Jensen, E. J., Honomichl, S., and Pan, L. L.: Boundary layer sources for the Asian anticyclone: Regional contributions to a vertical conduit, J. Geophys. Res., 118, 2560-2575, doi:10.1002/jgrd.50142, 2013.

Bernath, P. F., McElroy, C. T., Abrams, M. C., Boone, C. D., Butler, M., Camy-Peyret, C., Carleer, M., Clerbaux, C., Coheur, P.-F., Colin, R., DeCola, P., DeMazière, M., Drummond, J. R., Dufour, D., Evans, W. F. J., Fast, H., Fussen, D., Gilbert, K., Jennings, D. E., Llewellyn, E. J., Lowe, R. P., Mahieu, E., McConnell, J. C., McHugh, M., McLeod, S. D., Michaud, R., Midwinter, C., Nassar, R., Nichitiu, F., Nowlan, C., Rinsland, C. P., Rochon, Y. J., Rowlands, N., Semeniuk, K., Simon, P., Skelton, R., Sloan, J. J., Soucy, M.-A., Strong, K., Tremblay, P., Turnbull, D., Walker, K. A., Walkty, I., Wardle, D. A., Wehrle, V., Zander, R., and Zou, J.: Atmospheric Chemistry Experiment (ACE): Mission overview, Geophys. Res. Lett., 32, L15S01, doi:10.1029/2005GL022386, 2005.

Dee, D. P., Uppala, S. M., Simmons, A. J., Berrisford, P., Poli, P., Kobayashi, S., Andrae, U., Balmaseda, M. A., Balsamo, G., Bauer, P., Bechtold, P., Beljaars, A. C. M., van de Berg, L., Bidlot, J., Bormann, N., Delsol, C., Dragani, R., Fuentes, M., Geer, A. J., Haimberger, L., Healy, S. B., Hersbach, H., Hòlm, E. V., Isaksen, L., Kållberg, P., Köhler, M., Matricardi, M., McNally, A. P., Monge-Sanz, B. M., Morcrette, J.-J., Park, B.-K., Peubey, C., de Rosnay, P., Tavolato, C., Thépaut, J.-N., and Vitart, F.: The ERA-Interim reanalysis: configuration and performance of the data assimilation system, Q. J. Roy. Meteor. Soc., 137, 553-597, doi:10.1002/qj.828, 2011.

Dethof, A., O’Neill, A., Slingo, J. M., and Smit, H. G. J.: A mechanism for moistening the lower stratosphere involving the Asian summer monsoon, Q. J. Roy. Meteor. Soc., 125, 1079-1106, doi:10.1002/qj.1999.49712555602, 1999.
Fadnavis, S., Schultz, M. G., Semeniuk, K., Mahajan, A. S., Pozzoli, L., Sonbawne, S., Ghude, S. D., Kiefer, M., and Eckert, E.: Trends in peroxyacetyl nitrate (PAN) in the upper troposphere and lower stratosphere over southern Asia during the summer monsoon season: regional impacts, Atmos. Chem. Phys., 14, 12725-12743, doi:10.5194/acp-14-12725-2014, 2014.

Fastie, W.: Ebert Spectrometer Reflections, Phys. Today, 4, 37-43, 1991.

Fischer, H., Birk, M., Blom, C., Carli, B., Carlotti, M., von Clarmann, T., Delbouille, L., Dudhia, A., Ehhalt, D., Endemann, M., Flaud, J. M., Gessner, R., Kleinert, A., Koopman, R., Langen, J., López-Puertas, M., Mosner, P., Nett, H., Oelhaf, H., Perron, G., Remedios, J., Ridolfi, M., Stiller, G., and Zander, R.: MIPAS: an instrument for atmospheric and climate research, Atmos. Chem. Phys., 8, 2151-2188, doi:10.5194/acp-8-2151-2008, 2008.

Garny, H. and Randel, W. J.: Dynamic variability of the Asian monsoon anticyclone observed in potential vorticity and correlations with tracer distributions, J. Geophys. Res., 118, 13421-13433, doi:10.1002/2013JD020908, 2013.

Garny, H. and Randel, W. J.: Transport pathways from the Asian monsoon anticyclone to the stratosphere, Atmos. Chem. Phys., 16, 2703-2718, doi:10.5194/acp-16-2703-2016, 2016.

Gettelman, A., Kinnison, D. E., Dunkerton, T. J., and Brasseur, G. P.: Impact of monsoon circulations on the upper troposphere and lower stratosphere, J. Geophys. Res., 109, D22101, doi:10.1029/2004JD004878, 2004.

Glatthor, N., von Clarmann, T., Fischer, H., Funke, B., Grabowski, U., Höpfner, M., Kellmann, S., Kiefer, M., Linden, A., Milz, M., Steck, T., and Stiller, G. P.: Global peroxyacetyl nitrate (PAN) retrieval in the upper troposphere from limb emission spectra of the Michelson Interferometer for Passive Atmospheric Sounding (MIPAS), Atmos. Chem. Phys., 7, 2775-2787, doi:10.5194/acp7-2775-2007, 2007.

Grossmann, K. U., Offermann, D., Gusev, O., Oberheide, J., Riese, M., and Spang, R.: The CRISTA-2 mission, J. Geophys. Res., 107, 8173, doi:10.1029/2001JD000667, 2002.

Hanke, M.: Conjugate gradient type methods for ill-posed problems, John Wiley \& Sons, 1995.

Hintsa, E. J., Boering, K. A., Weinstock, E. M., Anderson, J. G., Gary, B. L., Pfister, L., Daube, B. C., Wofsy, S. C., Loewenstein, M., Podolske, J. R., Margitan, J. J., and Bui, T. P.: Troposphereto-stratosphere transport in the lowermost stratosphere from measurements of $\mathrm{H}_{2} \mathrm{O}, \mathrm{CO}_{2}, \mathrm{~N}_{2} \mathrm{O}$ and $\mathrm{O}_{3}$, Geophys. Res. Lett., 25, 2655-2658, doi:10.1029/98GL01797, 1998.

Hoffmann, L., Kaufmann, M., Spang, R., Müller, R., Remedios, J. J., Moore, D. P., Volk, C. M., von Clarmann, T., and Riese, M.: Envisat MIPAS measurements of CFC-11: retrieval, validation, and climatology, Atmos. Chem. Phys., 8, 3671-3688, doi:10.5194/acp-8-3671-2008, 2008.

Hoor, P., Fischer, H., Lange, L., Lelieveld, J., and Brunner, D.: Seasonal variations of a mixing layer in the lowermost stratosphere as identified by the $\mathrm{CO}-\mathrm{O}_{3}$ correlation from in situ measurements, J. Geophys. Res., 107, 4004, doi:10.1029/2000JD000289, 2002.

Hsu, C. J. and Plumb, R. A.: Nonaxisymmetric Thermally Driven Circulations and Upper-Tropospheric Monsoon Dynamics, J. Atmos. Sci., 57, 1255-1276, doi:10.1175/15200469(2000)057<1255:NTDCAU>2.0.CO;2, 2000. 
Kaufmann, M., Blank, J., Guggenmoser, T., Ungermann, J., Engel, A., Ern, M., Friedl-Vallon, F., Gerber, D., Grooß, J. U., Guenther, G., Höpfner, M., Kleinert, A., Kretschmer, E., Latzko, Th., Maucher, G., Neubert, T., Nordmeyer, H., Oelhaf, H., Olschewski, F., Orphal, J., Preusse, P., Schlager, H., Schneider, H., Schuettemeyer, D., Stroh, F., Suminska-Ebersoldt, O., Vogel, B., M. Volk, C., Woiwode, W., and Riese, M.: Retrieval of threedimensional small-scale structures in upper-tropospheric/lowerstratospheric composition as measured by GLORIA, Atmos. Meas. Tech., 8, 81-95, doi:10.5194/amt-8-81-2015, 2015.

Konopka, P., Grooß, J.-U., Günther, G., Ploeger, F., Pommrich, R., Müller, R., and Livesey, N.: Annual cycle of ozone at and above the tropical tropopause: observations versus simulations with the Chemical Lagrangian Model of the Stratosphere (CLaMS), Atmos. Chem. Phys., 10, 121-132, doi:10.5194/acp-10-121-2010, 2010.

Krishnamurti, T. N. and Bhalme, H. N.: Oscillations of a monsoon system. Part I. Observational aspects, J. Atmos. Sci., 33, 1937-1954, doi:10.1175/15200469(1976)033<1937:OOAMSP>2.0.CO;2, 1976.

Kunz, A., Konopka, P., Müller, R., and Pan, L. L.: Dynamical tropopause based on isentropic potential vorticity gradients, J. Geophys. Res., 116, D01 110, doi:10.1029/2010JD014343, 2011

Lait, L. R.: An Alternative Form for Potential Vorticity, J. Atmos. Sci., 51, 1754-1759, doi:10.1175/15200469(1994)051<1754:AAFFPV>2.0.CO;2, 1994.

Li, Q., Jiang, J. H., Wu, D. L., Read, W. G., Livesey, N. J., Waters, J. W., Zhang, Y., Wang, B., Filipiak, M. J., Davis, C. P., Turquety, S., Wu, S., Park, R. J., Yantosca, R. M., and Jacob, D. J.: Convective outflow of South Asian pollution: A global CTM simulation compared with EOS MLS observations, Geophys. Res. Lett., 32, L14826, doi:10.1029/2005GL022762, 2005.

McKenna, D. S., Konopka, P., Grooß, J.-U., Günther, G., Müller, R., Spang, R., Offermann, D., and Orsolini, Y.: A new Chemical Lagrangian Model of the Stratosphere (CLaMS) 1. Formulation of advection and mixing, J. Geophys. Res., 107, ACH15-1-ACH1515, doi:10.1029/2000JD000114, 2002.

Müller, R. and Günther, G.: A Generalized Form of Lait's Modified Potential Vorticity, J. Atmos. Sci., 60, 2229-2237, 2003.

Offermann, D., Grossmann, K.-U., Barthol, P., Knieling, P., Riese, M., and Trant, R.: Cryogenic Infrared Spectrometers and Telescopes for the Atmosphere (CRISTA) experiment and middle atmosphere variability, J. Geophys. Res., 104, 16311-16325, doi:10.1029/1998JD100047, 1999.

Pan, L. L., Bowman, K. P., Shaphiro, M., Randel, W. J., Gao, R.S., Campos, T., Favis, C., Schauffler, S., Ridley, B. A., Wei, J. C., and Barnet, C.: Chemical behavior of the tropopause observed during the Stratosphere-Troposphere Analyses of Regional Transport (START) experiment, J. Geophys. Res., 112, D18110, doi:10.1029/2007JD008645, 2007.

Park, M., Randel, W. J., Gettelman, A., Massie, S. T., and Jiang, J. H.: Transport above the Asian summer monsoon anticyclone inferred from Aura Microwave Limb Sounder tracers, J. Geophys. Res., 112, D16309, doi:10.1029/2006JD008294, 2007.

Park, M., Randel, W. J., Emmons, L. K., Bernath, P. F., Walker, K. A., and Boone, C. D.: Chemical isolation in the Asian monsoon anticyclone observed in Atmospheric Chemistry Ex- periment (ACE-FTS) data, Atmos. Chem. Phys., 8, 757-764, doi:10.5194/acp-8-757-2008, 2008

Penketi, S. A., Sandalls, F. J., and Lovelock, J. F.: Observations of peroxyacetyl nitrate (PAN) in air in Southern England, Atmos. Environ., 9, 139-140, doi:10.1016/0004-6981(75)90063-3, 1975.

Ploeger, F., Günther, G., Konopka, P., Fueglistaler, S., Müller, R., Hoppe, C., Kunz, A., Spang, R., Grooß, J.-U., and Riese, M.: Horizontal water vapor transport in the lower stratosphere from subtropics to high latitudes during boreal summer, J. Geophys. Res., 118, 8111-8127, doi:10.1002/jgrd.50636, 2013.

Ploeger, F., Gottschling, C., Griessbach, S., Grooß, J.-U., Guenther, G., Konopka, P., Müller, R., Riese, M., Stroh, F., Tao, M., Ungermann, J., Vogel, B., and von Hobe, M.: A potential vorticitybased determination of the transport barrier in the Asian summer monsoon anticyclone, Atmos. Chem. Phys., 15, 13145-13159, doi:10.5194/acp-15-13145-2015, 2015.

Popovic, J. M. and Plumb, R. A.: Eddy shedding from the upper tropospheric Asian monsoon anticyclone, J. Atmos. Sci., 58, 93-104, doi:10.1175/1520 0469(2001)058<0093:ESFTUT>2.0.CO;2, 2001.

Randel, W. J. and Park, M.: Deep convective influence on the Asian summer monsoon anticyclone and associated tracer variability observed with Atmospheric Infrared Sounder (AIRS), J. Geophys. Res., 111, D12314, doi:10.1029/2005JD006490, 2006.

Randel, W. J., Park, M., Emmons, L., Kinnison, D., Bernath, P., Walker, K. A., Boone, C., and Pumphrey, H.: Asian Monsoon Transport of Pollution to the Stratosphere, Science, 328, 611613, doi:10.1126/science.1182274, 2010.

Remedios, J. J., Leigh, R. J., Waterfall, A. M., Moore, D. P., Sembhi, H., Parkes, I., Greenhough, J., Chipperfield, M. P., and Hauglustaine, D.: MIPAS reference atmospheres and comparisons to V4.61/V4.62 MIPAS level 2 geophysical data sets, Atmos. Chem. Phys. Discuss., 7, 9973-10017, doi:10.5194/acpd-79973-2007, 2007.

Riese, M., Preusse, P., Spang, R., Ern, M., Jarisch, M., Grossmann, U., and Offermann, D.: Measurements of trace gases by the cryogenic infrared spectrometers and telescopes for the atmosphere CRISTA experiment, Adv. Space Res., 19, 563-566, doi:10.1016/S0273-1177(97)00172-5, 1997.

Riese, M., Spang, R., Preusse, P., Ern, M., Jarisch, M., Offermann, D., and Grossmann, K. U.: Cryogenic Infrared Spectrometers and Telescopes for the Atmosphere (CRISTA) data processing and atmospheric temperature and trace gas retrieval, J. Geophys Res., 104, 16349-16367, doi:10.1016/S0273-1177(97)00172-5, 1999.

Riese, M., Friedl-Vallon, F., Spang, R., Preusse, P., Schiller, C., Hoffmann, L., Konopka, P., Oelhaf, H., von Clarmann, T., and Höpfner, M.: GLObal limb Radiance Imager for the Atmosphere (GLORIA): Scientific objectives, Adv. Space Res., 36, 989-995, doi:10.1016/j.asr.2005.04.115, 2005.

Roberts, J. M.: The atmospheric chemistry of organic nitrates, Atmos. Environ. A-Gen., 24, 243-287, doi:10.1016/0960 1686(90)90108-Y, 1990.

Singh, H. B., Salas, L. J., and Viezee, W.: Global distribution of peroxyacetyl nitrate, Nature, 321, 588-591, doi:10.1038/321588a0, 1986.

Singh, H. B., Salas, L., Herlth, D., Kolyer, R., Czech, E., Avery, M., Crawford, J. H., Pierce, R. B., Sachse, G. W., Blake, D. R., 
Cohen, R. C., Bertram, T. H., Perring, A., Wooldridge, P. J., Dibb, J., Huey, G., Hudman, R. C., Turquety, S., Emmons, L. K., Flocke, F., Tang, Y., Carmichael, G. R., and Horowitz, L. W.: Reactive nitrogen distribution and partitioning in the North American troposphere and lowermost stratosphere, J. Geophys. Res., 112, D12S04, doi:10.1029/2006JD007664, 2007.

Spang, R., Arndt, K., Dudhia, A., Höpfner, M., Hoffmann, L., Hurley, J., Grainger, R. G., Griessbach, S., Poulsen, C., Remedios, J. J., Riese, M., Sembhi, H., Siddans, R., Waterfall, A., and Zehner, C.: Fast cloud parameter retrievals of MIPAS/Envisat, Atmos. Chem. Phys., 12, 7135-7164, doi:10.5194/acp-12-71352012, 2012.

Spang, R., Günther, G., Riese, M., Hoffmann, L., Müller, R., and Griessbach, S.: Satellite observations of cirrus clouds in the Northern Hemisphere lowermost stratosphere, Atmos. Chem. Phys., 15, 927-950, doi:10.5194/acp-15-927-2015, 2015.

Stephens, E. R.: The formation, reactions, and properties of peroxyacyl nitrates (PANS) in photochemical air pollution, Adv. Environ. Sci., 1, 119-147, 1969.

Tikhonov, A. N. and Arsenin, V. Y.: Solutions of ill-posed problems, Winston, Washington D.C., USA, 1977.

Ungermann, J.: Improving retrieval quality for airborne limb sounders by horizontal regularisation, Atmos. Meas. Tech., 6, 15-32, doi:10.5194/amt-6-15-2013, 2013.

Ungermann, J., Kalicinsky, C., Olschewski, F., Knieling, P., Hoffmann, L., Blank, J., Woiwode, W., Oelhaf, H., Hösen, E., Volk, C. M., Ulanovsky, A., Ravegnani, F., Weigel, K., Stroh, F., and Riese, M.: CRISTA-NF measurements with unprecedented vertical resolution during the RECONCILE aircraft campaign, Atmos. Meas. Tech., 5, 1173-1191, doi:10.5194/amt-5-1173-2012, 2012.

Ungermann, J., Pan, L. L., Kalicinsky, C., Olschewski, F., Knieling, P., Blank, J., Weigel, K., Guggenmoser, T., Stroh, F., Hoffmann, L., and Riese, M.: Filamentary structure in chemical tracer distributions near the subtropical jet following a wave breaking event, Atmos. Chem. Phys., 13, 10517-10534, doi:10.5194/acp13-10517-2013, 2013.
Ungermann, J., Blank, J., Dick, M., Ebersoldt, A., Friedl-Vallon, F., Giez, A., Guggenmoser, T., Höpfner, M., Jurkat, T., Kaufmann, M., Kaufmann, S., Kleinert, A., Krämer, M., Latzko, T., Oelhaf, H., Olchewski, F., Preusse, P., Rolf, C., Schillings, J., Suminska-Ebersoldt, O., Tan, V., Thomas, N., Voigt, C., Zahn, A., Zöger, M., and Riese, M.: Level 2 processing for the imaging Fourier transform spectrometer GLORIA: derivation and validation of temperature and trace gas volume mixing ratios from calibrated dynamics mode spectra, Atmos. Meas. Tech., 8, 24732489, doi:10.5194/amt-8-2473-2015, 2015.

Vogel, B., Günther, G., Müller, R., Grooß, J.-U., Hoor, P., Krämer, M., Müller, S., Zahn, A., and Riese, M.: Fast transport from Southeast Asia boundary layer sources to northern Europe: rapid uplift in typhoons and eastward eddy shedding of the Asian monsoon anticyclone, Atmos. Chem. Phys., 14, 12745-12762, doi:10.5194/acp-14-12745-2014, 2014.

Vogel, B., Günther, G., Müller, R., Grooß, J.-U., and Riese, M.: Impact of different Asian source regions on the composition of the Asian monsoon anticyclone and of the extratropical lowermost stratosphere, Atmos. Chem. Phys., 15, 13699-13716, doi:10.5194/acp-15-13699-2015, 2015.

Wattenbach, R. and Moritz, K.: Astronomical Shuttle Pallet Satellite (ASTRO-SPAS), Acta Astronaut., 40, 723-732, 1997.

Wiegele, A., Glatthor, N., Höpfner, M., Grabowski, U., Kellmann, S., Linden, A., Stiller, G., and von Clarmann, T.: Global distributions of $\mathrm{C}_{2} \mathrm{H}_{6}, \mathrm{C}_{2} \mathrm{H}_{2}, \mathrm{HCN}$, and PAN retrieved from MIPAS reduced spectral resolution measurements, Atmos. Meas. Tech., 5, 723-734, doi:10.5194/amt-5-723-2012, 2012.

WMO: Meteorology - a three-dimensional science: Second session for the commission for aerology, WMO Bull., 6, 134-138, 1957.

Wunderli, S. and Gehrig, R.: Influence of temperature on formation and stability of surface PAN and ozone. A two year field study in Switzerland, Atmos. Environ. A-Gen., 25, 1599-1608, doi:10.1016/0960-1686(91)90018-3, 1991. 